\title{
Food Habit of Hazel Grouse in Hokkaido, Japan
}

\author{
Yuzo Fujimaki*
}

\begin{abstract}
The food habits of Hazel Grouses Bonasa bonasia were analyzed based on crop contents of 237 birds shot from early October to late January in 1994/95 and 1995/ 96 and from February to September 1996 in Hokkaido, Japan. Crop contents were greater in December and January than in October and November. Considerable seasonal variation in major food items was observed: buds of deciduous broad-leaved trees from November to February; leaves of herbaceous plants during the snow-free season; seeds during June and July, and fruits from October to January. In addition to these food items, arthropods were eaten frequently, although in small amounts, in June and July. Although the food habits of this species are basically similar in both Europe and Hokkaido, in Hokkaido the buds of a wider range of tree species were eaten in winter and the fruits of lianas such as Vitis coignetiae and Actinidia arguta were important foods during autumn and winter in Hokkaido.
\end{abstract}

Key words: Crop contents, Food habit, Hazel grouse, Hokkaido.

キーワード：そ囊内容物, 食性, エゾライチョウ，北海道.

\section{Introduction}

The Hazel Grouse Bonasa bonasia is widely distributed from Scandinavia to the Okhotsk Sea coast and on Sakhalin and Hokkaido, Japan (Johnsgard 1983). In Hokkaido, Hazel Grouse occur in most forested areas, but are not present at high altitudes (Fujimaki \& Konishi 1996).

Throughout their range, Hazel Grouse feed on green plants, berries, fruits, and buds and catkins of deciduous broad-leaved trees. The foods used are dependent on their availability in their habitats. Many studies have been previously published on food habits of Hazel Grouse throughout the year (Semenov-Tyan-Shanskii 1959, Ivanter 1962, Zhao 1977, Bergmann et al. 1982, 1996, Bergmann \& Klaus 1994), especially in autumn and winter (Salo 1971, Yang 1993). Food items eaten by Hazel Grouse, however, might differ among different areas within their wide range depending on the species composition of plants available in their habitats. Some plant species utilized intensively by Hazel Grouse in Europe are rare or absent in their habitats in Hokkaido. In particular, Vaccinium spp., which comprise major autumn food in Europe (Ahnlund \& Helander 1975) do not occur as food resources in low altitudes in most part of Hokkaido. However, fruits of liana are abundant and available in autumn in Hokkaido.

This paper describes the food habits of Hazel Grouse in Hokkaido based on crops collected from different areas of Hokkaido from 1994 to 1996.

Received 14 September 2001, Revised 13 June 2002, Accepted 9 September 2002.

* Laboratory of Wildlife Ecology, Obihiro University of Agriculture and Veterinary Medicine, Inada, Obihiro, 080-8555 Japan.

Present address: Higashi 4, Kita 2-6-1, Bibai, 072-0005 Japan. 


\section{Materials and Methods}

Crop samples were obtained from 216 birds shot by hunters during the hunting seasons (1 October to 31 January) of 1994/95 and 1995/96 (numbers of samples were 86 in October, 82 in November and 22 in December and 26 in January, respectively) and 21 birds shot specifically for this purpose from February to September 1996 (1 in February, 2 in April, 2 in June, 3 in July, 9 in August and 4 in September) in various areas of Hokkaido. Frozen crops were then sent to our laboratory. Each crop's contents was weighed to the nearest $0.1 \mathrm{~g}$, then was sorted into food items, which were then identified. Afterward, the samples were dried at $70^{\circ} \mathrm{C}$ for $48 \mathrm{~h}$, then weighed to the nearest $0.01 \mathrm{~g}$. Food items were indicated as traces when its weight was less than $0.01 \mathrm{~g}$.

Data from different age-sex groups and years were combined. It is appropriate to combine data from different age groups, because there were no crops of juveniles from June to September, when food habits differ between juvenile and adult birds (Bergmann et al. 1996). In addition, data from January and February, June and July, and August and September were combined because of small samples in February, April and from June to September. Empty crops were excluded from the data in calculating frequency of occurrence, i.e. the percent of crops containing a given food item.

In this paper means are presented with standard deviations of the mean. MannWhitney's U, Kruskal-Wallis or $\chi^{2}$ tests was used to compare means or proportions between months.

\section{Results}

\section{Total weight of crop contents}

A total of 237 crops were examined. Of them 15\% of the crops (1 in August, 19 in October and 15 in November) were empty. The proportion of empty crops decreased from $19 \%$ in October and $15 \%$ in November to $0 \%$ in December and January.

Individual crop contents ranged from 0 to $49.4 \mathrm{~g}$ wet weight, with a mean of $5.3 \pm 6.7$ $\mathrm{g}(\mathrm{n}=237)$ and from 0 to $22.5 \mathrm{~g}$ dry weight, with a mean of $1.88 \pm 3.02 \mathrm{~g}$. During hunting seasons, when relatively many crops were obtained, the mean of wet content weights

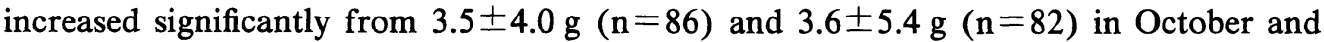
November respectively to $9.7 \pm 7.4 \mathrm{~g}(\mathrm{n}=22)$ and $12.6 \pm 10.1 \mathrm{~g}(\mathrm{n}=26)$ in December and January, respectively $(H=47.654, P<0.01)$. Corresponding values for dry contents weight were $0.8 \pm 0.8 \mathrm{~g}$ in October, $1.2 \pm 2.0 \mathrm{~g}$ in November, $4.2 \pm 3.9$ in December and 5.9 $\pm 4.8 \mathrm{~g}$ in January, respectively, showing significantly a similar seasonal change $(H=$ 65.310, $P<0.01)$.

\section{Frequency of occurrence of food items}

In April two crops contained only Salix sp. The major food items, expressed by frequency of occurrence, were leave of herbaceous plants, seeds and arthropods in June and July, and leaves, seeds, fruits and arthropods in August and September (Table 1). In October buds of deciduous broad-leaved trees and fruits of liana were eaten frequently. In 
Table 1. Frequencies of occurrence (\%) of food items in Hazel Grouse crop contents.

\begin{tabular}{|c|c|c|c|c|c|c|c|c|c|}
\hline Month & $\begin{array}{c}\text { No. of } \\
\text { samples* }\end{array}$ & Bud & Catkin & Shoot & Leaf & Seed & Fruit, berry & Arthropods & Gastropods \\
\hline Apr. & 2 & 100 & & & & & & & \\
\hline June \& July & 5 & & & & 40 & 80 & 20 & 60 & \\
\hline Aug. \& Sep. & 12 & 8 & & & 33 & 42 & 42 & 33 & \\
\hline Oct. & 67 & 40 & & & 28 & 10 & 70 & 15 & 1 \\
\hline Nov. & 67 & 64 & & 4 & 54 & 28 & 40 & 2 & \\
\hline Dec. & 22 & 82 & 14 & 9 & 41 & 5 & 77 & & \\
\hline Jan. \& Feb. & 27 & 96 & 8 & 23 & 4 & 4 & 35 & & \\
\hline
\end{tabular}

*Empty crops were excluded.

November and December frequency of occurrence of buds became high, and leaves and fruits remained important as food. In January and February, the crops consisted entirely of buds of deciduous broad-leaved trees, shoots and fruits (Table 1). The frequency of occurrence of food items showed significant seasonal changes $\left(\chi^{2}=140.320, d f=30, P<\right.$ $0.01)$.

Hazel Grouse were recorded eating the bud of Salix, Betula, Alnus, Magnolia obovata, Prunus, Sorbus, Maackia amurensis, Euonymus, Acer, Rhododendron and Fraxinus. Of these, the buds of Betula, Prunus and Acer were eaten more often than those of other genera, with frequencies of occurrence of 27,17 and $13 \%$, respectively.

Leaves identified in crops were Taxus cuspidata, Abies sachalinensis, Oxalia sp. and Trifolium repens. Of these green leaves of $T$. repens occurred in crop contents from August to December, with especially high frequencies in October (21\%) and November (31\%). Leaves of Oxalia sp. were not often eaten. Needles of $T$. cuspidata and $A$. sachalinensis were seen only rarely in the crop contents. Most leaves remained to be unidentified because they were fragmented into small pieces.

Of the seeds found in the crops, Rhus trichocarpa occurred in November and January. In addition, seeds identified to the family or genus level were Picea, Abies, Betula, Alnus, Rubus, Labiatae, Compositae, Oxalia, Carex, Viola, Umbellifefae and Gramineae. Most of the seeds were not identified.

Fruits eaten frequently by Hazel Grouse were Sambucus siebloldiana in July and August, Vitis coignetiae and Actinidia arguta from September to January. Especially, $V$. coignetiae and $A$. arguta were the most frequent food items in October and November, accounting for $25 \%$ and $40 \%$, respectively, of the contens of crops containing food items in October, and $15 \%$ and $24 \%$, respectively, in November. In addition, fruits eaten seldom were Viscum album in November, Sorbus commixta in October and December, Pachysandra terminalis in September and October, Celastrus orbiculatus from October to January, and Actinidia polygama in November.

Animal matters eaten included Gastropoda, Araneae, Ephemeroptera, Plecoptera, Dermaptera, Orthoptera (Acrididae), Heteroptera (Carbula humerigera), Hemiptera (Cercopidae), Lepidoptera, Coleoptera (Ectinus sericeus, Harmonia axyrids, Henosepilachena vigintiotomaculata, Gallerucida bitasciata, Chrysomelidae, Plyllobius sp.) and 
Table 2. Mean ( \pm SD) dry weight $(\mathrm{g})$ of food items in Hazel Grouse crop contents.

\begin{tabular}{|c|c|c|c|c|c|c|c|c|c|}
\hline Month & $\begin{array}{c}\text { No. of } \\
\text { samples }\end{array}$ & Bud & Catkin & Shoot & Leaf & Seed & $\begin{array}{l}\text { Fruit, } \\
\text { berry }\end{array}$ & $\begin{array}{l}\text { Arthro- } \\
\text { pods }\end{array}$ & $\begin{array}{c}\text { Gastro- } \\
\text { pods }\end{array}$ \\
\hline Apr. & 2 & $3.65 \pm 3.32$ & & & & & & & \\
\hline June \& July & 5 & & & & $0.06 \pm 0.13$ & $0.44 \pm 0.41$ & + & $0.03 \pm 0.03$ & \\
\hline Aug. \& Sep. & 13 & + & & & $0.10 \pm 0.25$ & $0.12 \pm 0.36$ & $0.78 \pm 1.33$ & $0.01 \pm 0.03$ & \\
\hline Oct. & 86 & $0.11 \pm 0.26$ & & & $0.06 \pm 0.17$ & $0.01 \pm 0.09$ & $0.57 \pm 0.81$ & $0.01 \pm 0.09$ & + \\
\hline Nov. & 82 & $0.43 \pm 1.12$ & & + & $0.10 \pm 0.25$ & $0.11 \pm 0.34$ & $0.54 \pm 1.56$ & + & \\
\hline Dec. & 22 & $2.09 \pm 2.68$ & $0.06 \pm 0.22$ & $0.03 \pm 0.11$ & $10.12 \pm 0.35$ & $0.14 \pm 0.65$ & $1.72 \pm 2.29$ & & \\
\hline Jan. \& Feb. & 27 & $4.58 \pm 4.92$ & $0.03 \pm 0.10$ & $0.21 \pm 0.77$ & $7+$ & $0.01 \pm 0.06$ & $1.03 \pm 2.10$ & & \\
\hline
\end{tabular}

+ indicate weight less than $0.01 \mathrm{~g}$

Hymenoptera (Ichneumonidae, Formica truncorum, Formicidae). Of these the Lepidoptera were larvae and insects of other order were imagoes.

\section{Dry weight of food items}

The dry weight of buds in the crops increased significantly from October and November to December and January $(H=94.389, P<0.01)$, showing a seasonal change similar to that seen in frequency of occurrence of buds (Table 2). Buds comprised $14 \%$ of dry weight of crop contents in October. This proportion increased to $36 \%$ in November, $80 \%$ in December and $78 \%$ in January. Seeds comprised $0.44 \pm 0.41 \mathrm{~g}$ dry weight, which was $83 \%$ of the dry weight of crop contents in June and July. After July, this decreased significantly to less than $0.4 \mathrm{~g}$ (Table $2, H=35.427,0.01<P<0.05$ ). Fruits comprised less than $1 \mathrm{~g}$ in dry weight between June and November, although the frequency of occurrence was relatively high (Tables 1 and 2). They increased significantly from $1.03 \pm 2.10 \mathrm{~g}$ to $1.72 \pm 2.29 \mathrm{~g}$ between December and February $(H=20.900, P<$ 0.01 ), in spite of a rather low frequency of occurrence in January and February. Other food items, such as catkins, shoots, leaves and animal matter, were less than $0.3 \mathrm{~g}$ (Table 2).

\section{Discussion}

There was a tendency for crop contents to weigh more in winter than in other seasons. Similar tendencies in crop content weight have been observed in Europe, with 4 to 10 times as much food in winter than in summer (Semenov-Tyan-Shanskii 1959, Ahnlund \& Helander 1975). Larger crop content weights in winter than in other seasons have also been reported for other species of tetraonids, Spruce Grouse Dendragapus canadensis and Willow Grouse Lagopus lagopus (Irving et al. 1967, Pendergast \& Boag 1970). They suggested that there was a greater probability of collecting a bird with a full crop in winter because the food intake was related to day length and the day was shorter in the winter. This may also be the case for Hazel Grouse. In addition, Hazel Grouse need to eat more food in winter, when requirements are greater than in other seasons (Fujimaki et al. 1994).

The results indicate a distinct dietary shift through the year. In April, when the 
ground is still covered with snow and food on the ground is not available, Hazel Grouse take mainly buds from the tree canopy. In June and July, the foods eaten most frequently were seeds, green leaves of herbaceous plants and arthropods. However, leaves and arthropods were not as important as indicated by frequency of occurrence, because they were eaten only in small amount. In August and September the major food items were fruits and green leaves. Seeds and animal matter were eaten often, although in small amount. In October and November, buds and fruits were the most important foods. From December to Febuary, the major food items were buds and fruites. Overall, plant matter comprised most of the food throughout the year, in addition to small amount of animal matter in summer and autumn. Such seasonal changes in food habits have been documented for Hazel Grouse throughout their wide range (Donaurov 1947, SemenovTyan-Shanskii 1959, Mishin 1960, Ivanter 1962, Nechaev 1968, Salo 1971, Ahnlund \& Helander 1975, Zbinden 1979, Bergmann et al. 1982, 1996, Bergmann \& Klaus 1994). There were no basic differeces in the food habits of Hazel Grouse between Europe and Hokkaido.

However, there are some diffrences in the importance of fruits during winter and in composition of plant species used by Hazel Grouse. In Hokkaido, fruits continued to be the most important food in December and January. In general, the first snow falls in mid-October and a continuous snow cover over $50 \mathrm{~cm}$ in depth is present from early December to early May in forested areas of low and middle altitudes in Hokkaido. In this period, fruits of liana are available in the tree canopy. The increased amounts of fruits eaten in this period relates to availability of these fruits. Secondly, there is diffrence in the composition of food plant species used by Hazel Grouse in Hokkaido and Europe. In Europe the most important winter foods are buds and catkins of birch and/or alder (Uusvaara 1963, Salo 1971, Ahnlund \& Helander 1975, Swenson 1993). In Hokkaido, however, buds of many species of deciduous broad-leaved trees were utilized as winter foods. Such is also the case for Hazel Grouse in the southern part of the Russian Far East (Nechaev \& Fujimaki 1997) and north-eastern China (Yang 1993). In the southern part of the Russian Far East buds of Populus, Chosenia, Salix, Alnus, Betula, Carpinus, Malus, Micromeles, Padus, Acer, and Corylus were eaten with frequency of occurrence exceeding 50\% (Nechaev \& Fujimaki 1997). In north-eastern China, buds of Acer, Populus, Corylus, Betula and Salix are the major foods in winter (Yang 1993). These differences are due to difference in plant species composition and the great species richness of the flora in the southern part of the Far East. In Europe, berries of Vaccinium and Empetrum are important foods in autumn (Salo 1971). In contrast to this, fruits of Vitis coignetiae and Actinidia arguta were important foods in autumn and winter in Hokkaido.

In conclusion, Hazel Grouse exhibit flexibility in their food habits according to the availability of plant species in their habitats.

\section{Acknowledgments}

I wish to thank Dr. I. Hayashi, Dr. M. Iwasa, Dr. K. Onoyama and Dr. S. Saito for identifiying food items and Dr. J. E. Swenson for reviewing the manuscript. I would like 


\section{to thank also the Hokkaido Prefectural Government for collecting the Hazel Grouse crops through the cooperation of the Hokkaido Hunters' Society.}

\section{References}

Ahnlund, H. \& Helander, B. 1975. The food of the hazel grouse (Tetrastes bonasia) in Sweden. Viltrevy 9: 221-254.

Bergmann, H.-H. \& Klaus, S. 1994. Distribution, status and limiting factors of hazel grouse (Bonasa bonasia) in central Europe, particularly in Germany. Gibier Faune Sauvage 11 (Special number part 2): 5-32.

Bergmann, H.-H., Klaus, S., Müller, F., Scherzinger, W., Swenson, J. E. \& Wiesner, J. 1996. Dis Haselhühner, Bonasa bonasia und $B$. sewerzowi, Westrap Wissenschaften, Magdeburg.

Bergmann, H.-H., Klaus, S., Müller, F. \& Wiesner, J. 1982. Das Haselhuhn, Bonasa bonasia, 2. Auflage. A. Ziemsen Verlag, Wittenberg Lutherstadt.

Donaurov, S. S. 1947. Ryabchik v Pechoro-Ilychskom zapovednike. Trudy Pechoro-Ilychskogo gosudarstvennogo zapovednika 4: 77-122. (In Russian).

Fujimaki, Y. \& Konishi, H. 1996. Distribution and abundance of Hazel Grouse in Hokkaido, Japan, based on questionnaire. Journal of Yamashina Institute for Ornithology 28: 81-91 (In Japanese with English abstract).

Fujimaki, Y., Miyazawa, Y. \& Sasaoka, K. 1994. Diet of Hazel Grouse and diet intake in captivity. Japanese Journal of Ornithology 43: 49-59. (In Japanese with English summary).

Irving, L., West, G. C. \& Peyton, L. J. 1967. Winter feeding program of Alaska willow ptarmigan shown by crop contents. Condor 69: 69-77.

Ivanter, E. V. 1962. K biologii ryabchika v Karelii. Ornitologiya 4: 87-98. (In Russian).

Johnsgard, P. A. 1983. The Grouse of the World. University of Nebraska Press, Lincoln.

Mishin, I. P. 1960. K biologii teterevidnykh ptits na Sakhaline. Ornitologiya 3: 251-258. (In Russian).

Nechaev, A. V. 1968. Osobennosti pitaniya ryabchika v kedrovo-shirokolistvennykh lesakh Primor'ya i Nizhnego Priamur'ya. Resursy teterevidnykh ptits v SSSR, 55-57.

Nechaev, A. V. \& Fujimaki, Y. 1997. The plant species eaten by hazel grouse in the southern part of the Russian Far East. Research Bulletin of Obihiro University, Natural Science 20: 133-139.

Pendergast, B. A. \& Boag, D. A. 1970. Seasonal changes in diet of spruce grouse in central Alberta. Journal of Wildlife Management 34: 605-611.

Salo, L. J. 1971. Autumn and winter diet of the hazel grouse (Tetrastes bonasia L.) in northeastern Finnish Lapland. Annales Zoologici Fennici 8: 543-546.

Semenov-Tyan-Shanskii, O. I. 1959. Ekologiya teterevinykh ptits. Trudy Laplandskogo gosudarstvennogo zapovednika 5: 1-319. (In Russian).

Swenson, J. E. 1993. The importance of alder to hazel grouze in Fennoscandian boreal forest: evidence from four levels of scale. Ecography 16: 37-46.

Uusvaara, O. 1963. The structure of the habitats of the hazel grouse. Suomen Riista 16: 31-45. (In Finnish with English summary).

Yang, B. 1993. On food features and nutrient analysis of hazel grouse in bud-feeding periods. Acta Zoologica Sinica 39: 48-55. (In Chinese with English summary).

Zbinden, N. 1979. Zur Okologie des Haselhuhns Bonasa bonasia in den Buchenwaldem des Chasseral, Faltenjura. Ornithologische Beobachter 76: 169-214.

Zhao, Z. 1977. Ecological studies of the hazel grouse in Chanbai Shan area. Acta Zoologica Sinica 23: 324-335. (In Chinese with English summary). 


\section{北海道におけるエゾライチョウの食性}

北海道のエゾライチョウBonasa bonasia の食性について, 237 例のそ囊内容物にもとづいて 調べた。得られたそ囊数は, 狩猟期の 1994/95 年と 1995/96 年の 10 月〜 1 月の 216 例, 非狩猟 期の 1996 年 2 9 月の 21 例である。そ囊内容物の湿重量を計測した後, 各食物項目に区分して 乾燥し, 各食物項目ごとに乾重量を計測した。各食物項目について月ごとに出現頻度と乾重量 で示した。調べたそ囊内容物 237 例のうち，35 例 (15\%) は空であった。そ囊内容物の湿重量は $0 \sim 49.4 \mathrm{~g}$, 平均 (土標準偏差, 以下同様) $5.3 \pm 6.7 \mathrm{~g}(\mathrm{n}=237)$, 乾重量は 0 22.5 g, 平均 1.88 土 $3.02 \mathrm{~g}$ であった。例数の多かった 10 月〜 1 月についてみると, 湿重量, 乾重量とも 10,11 月よ り 12,1 月で有意に大きかった。出現頻度の高かった食物は, 6,7 月には草本類の葉, 種子, 節 足動物, 8,9 月には葉, 種子, 果実, 節足動物, 10 月には落葉広葉樹の冬芽, ヤマブドウとサ ルナシの果実, 11,12 月には冬芽, 葉, 果実, 1, 2 月には冬芽であった。これらのうち, 同定で きたのは, 冬芽では, ヤナギ類, カンバ類, ハンノキ類, ホオノキ, サクラ類, ナナカマド類, イヌエンジュ, ニシキギ類, カエデ類, ツツジ類, トネリコ類であった。葉では, イチイ, ト ドマツ, カタバミ類, シロツメクサであった。種子では, ウルシ, トゥヒ類, トドマッ, カン バ類，ハンノキ類，キイチゴ類，シソ類，カタバミ類，スゲ類，スミレ類であった。果実では, 7, 8 月には二ワトコ, 10 月以降にはヤマブドゥ, サルナシ, マタタビ, フッキソゥ, ツルゥメ モドキ, ナナカマドであった。動物では, カタッムリ類, クモ類, カゲロウ類, カワゲラ類, 八サミムシ類, バッ夕類, カメムシ類，アワフキムシ類，鱗翅類，甲虫類，アリ類であった。 乾重量でみた主要な食物は，6,7 月には種子，8～9 月には葉，種子，果実，10１2 月には冬芽, 葉，種子，果実，1〜2月には冬芽と果実であった。北海道における食性をヨーロッパと比べる と，どちらも植物食である点では基本的に同じであるが，北海道では樹種の多さを反映して多 くの落葉広葉樹の冬芽を利用し，ヤマブドウやサルナシといった募植物の果実を秋から地表が 雪で覆われる厳冬期までよく食べていた。

藤巻裕蔵：帯広畜産大学畜産環境科学科野生動物管理学研究室. T080-8555 帯広市稲田町 西 2 線 11.

現住所： $=072-0005$ 美唄市東 4 条北 2丁目 6-1. 